Article

\title{
Tartary Buckwheat Genetic Diversity in the Himalayas Associated with Farmer Landrace Diversity and Low Dietary Dependence
}

\author{
Weijuan Huang ${ }^{1}$, Devra I. Jarvis ${ }^{2,3}$, Selena Ahmed ${ }^{4, *}$ (1) and Chunlin Long ${ }^{1,5, *}$ \\ 1 College of Life and Environmental Sciences, Minzu University of China, Beijing 100081, China; \\ huang@muc.edu.cn \\ 2 Bioversity International, Via dei Tre Denari, 472/a, 00054 Maccarese, RM, Italy; d.jarvis@cgiar.org \\ 3 Department of Crop and Soil Sciences, Washington State University, Pullman, WA 99164, USA \\ 4 Sustainable Food and Bioenergy Systems Program, Department of Health and Human Development, \\ Montana State University, Bozeman, MT 59717, USA \\ 5 Kunming Institute of Botany, Chinese Academy of Sciences, Kunming 650201, China \\ * Correspondence: selena.ahmed@montana.edu (S.A.); long.chunlin@muc.edu.cn (C.L.); \\ Tel.: +86-01-6893-0381 (C.L.)
}

Received: 28 August 2017; Accepted: 3 October 2017; Published: 10 October 2017

\begin{abstract}
While crop genetic diversity supports ecological processes and food security, there have been few cross-cultural studies evaluating the influence of cultural and dietary factors on the conservation of genetic resources. This study examines genetic diversity patterns of tartary buckwheat in 18 smallholder farming communities across five regions of China (Yunnan Province, Tibet Autonomous Region and Sichuan Province) and Bhutan managed by Yi, Tibetan, and Bhutanese farmers using ethnobotanical surveys and DNA barcoding. Findings emphasize that high dietary dependence linked to a single crop may result in simplification of genetic diversity as well as agricultural systems and landscapes more broadly. We advocate for the diversification of crops in agricultural systems as well as diets through the integration of scientific research and farmers' ecological knowledge and practices towards meeting global food security while supporting environmental well-being through biodiversity conservation.
\end{abstract}

Keywords: tartary buckwheat; genetic diversity; dietary dependence; landrace diversity; agricultural systems

\section{Introduction}

Crop genetic diversity is a key dimension of overall biodiversity, supporting multiple ecological processes at the population, community and ecosystem levels, including primary productivity, population recovery from disturbance, interspecific competition, community structure, and energy and nutrient fluxes [1]. In agricultural and food systems, crop genetic diversity is valued for its contribution to food security by enhancing farm-level resilience to environmental shocks [2] such as climate change [3]. Crop genetic diversity further provides a range of nutrients, micronutrients, and phytochemicals that support dietary quality and health outcomes [4].

Multiple mechanisms influence crop genetic diversity, such as genetic drift, natural selection, migration, and cultural and socioeconomic variables [5-8] including farmers' ecological knowledge, management practices, seed exchange and selection [9]. Farmers dynamically manage crops through a continuous process of experimentation, innovation, and exchange that may serve to enhance, conserve, or reduce crop genetic diversity [10]. Numerous studies highlight the role of traditional ecological knowledge and associated practices for supporting crop genetic diversity [11-14], such as 
selecting crop landraces with preferred nutrient profiles or those that are relatively more resilient to climate variability [15]. Neighborhood groups [9] and marriage exchanges are other social factors that shape crop diversity at local and regional levels [16-19].

While ecological, cultural, and socioeconomic factors influence crop genetic diversity, few studies have examined the influence of cultural factors on the genetic diversity of globally minor crops [7,19]. Tartary buckwheat (Fagopyrum tataricum (L.) Gaertn.; Polygonaceae) is a minor crop based on global distribution that serves as a major staple food for several sociolinguistic groups in the eastern Himalayas, including the Yi, Tibetans, and Bhutanese [12]. Buckwheat (tartary buckwheat) is believed to originate in the region of China encompassing Sichuan, Yunnan, and Tibet [20] where it was domesticated [21]. Today, buckwheat is primarily distributed in Bhutan and southwestern China [22,23]. Buckwheat is valued for food security in the Himalayas due to its cold-resistant character, short growth period [24], and nutrient-dense and rich antioxidant profile [25]. In particular, the Yi of China's Sichuan Province value buckwheat as a dietary staple for livestock feed, as well as part of their creation myth and festivals [26]. Fossil pollen evidence suggests that buckwheat was part of Yi diets over a thousand years ago [27]. Buckwheat is also commonly used as a medicinal tonic and beverage in several eastern Asian countries including China, Japan, and Korea [25].

DNA barcoding [28] was applied to assess variation in DNA sequences of buckwheat samples within and among study sites. As the number of DNA barcode sequences accumulates, however, these data will provide a unique 'horizontal' genomics perspective with broad implications [29]. Hou et al. [30] found two separate subgroups of tartary buckwheat clustered through studying the population genetic structure using SSR (simple sequence repeat) data. One group was mainly distributed in Nepal, Bhutan and the Yunnan-Guizhou Plateau regions of China; the other group was mainly derived from the Loess Plateau regions, Hunan and Hubei of China and USA. By using AFLP (amplified fragment length polymorphism) and ISSR (inter-simple sequence repeat) markers [31], it showed that the highest genetic diversity was presented in accessions from Yunnan which is considered the center of origin of buckwheat. Although the genetic diversity of tartary buckwheat have been studied by SSR [30], AFLP and ISSR [31], DNA barcoding can complement the current research and broaden our understanding of both phylogenetic signal and population-level variation.

This study examines the relationship between agricultural management, dietary dependence, geography, and morphological factors with buckwheat genetic diversity. Research was carried out across southwestern China and Bhutan using ethnobotanical surveys on agricultural management practices and diets coupled with DNA barcoding. We hypothesized the following: (1) smallholder communities that manage and identify a greater number of buckwheat landraces (named farmer varieties) will have greater buckwheat genetic diversity, (2) communities that have greater dietary dependence on buckwheat will also maintain greater buckwheat genetic diversity and, (3) buckwheat genetic differentiation varies with geography. The ultimate translational goal of this research is to inform the conservation of crop genetic resources towards enhancing local and global food security and overall biodiversity through diversification of agricultural systems and diets.

\section{Materials and Methods}

\subsection{Study Sites}

Fieldwork was carried out in 18 smallholder farming communities in three regions within China (Sichuan, Yunnan \& Tibet) and two regions in Bhutan (Thimphu \& Paro) (Figure 1) managed by Yi, Tibetan, and Bhutanese farmers including six smallholder communities in Sichuan, six communities in Yunnan, three communities in Tibet, one community in Thimphu, and two communities in Paro. Study regions were selected on the basis of the literature as either within the region encompassing the place of origin of buckwheat [32], maintaining diverse buckwheat genetic resources [33], and/or having expansive areas of buckwheat cultivation [34]. Study sites were further selected to encompass the range of agroclimatic conditions where buckwheat grows in the Himalayas. 


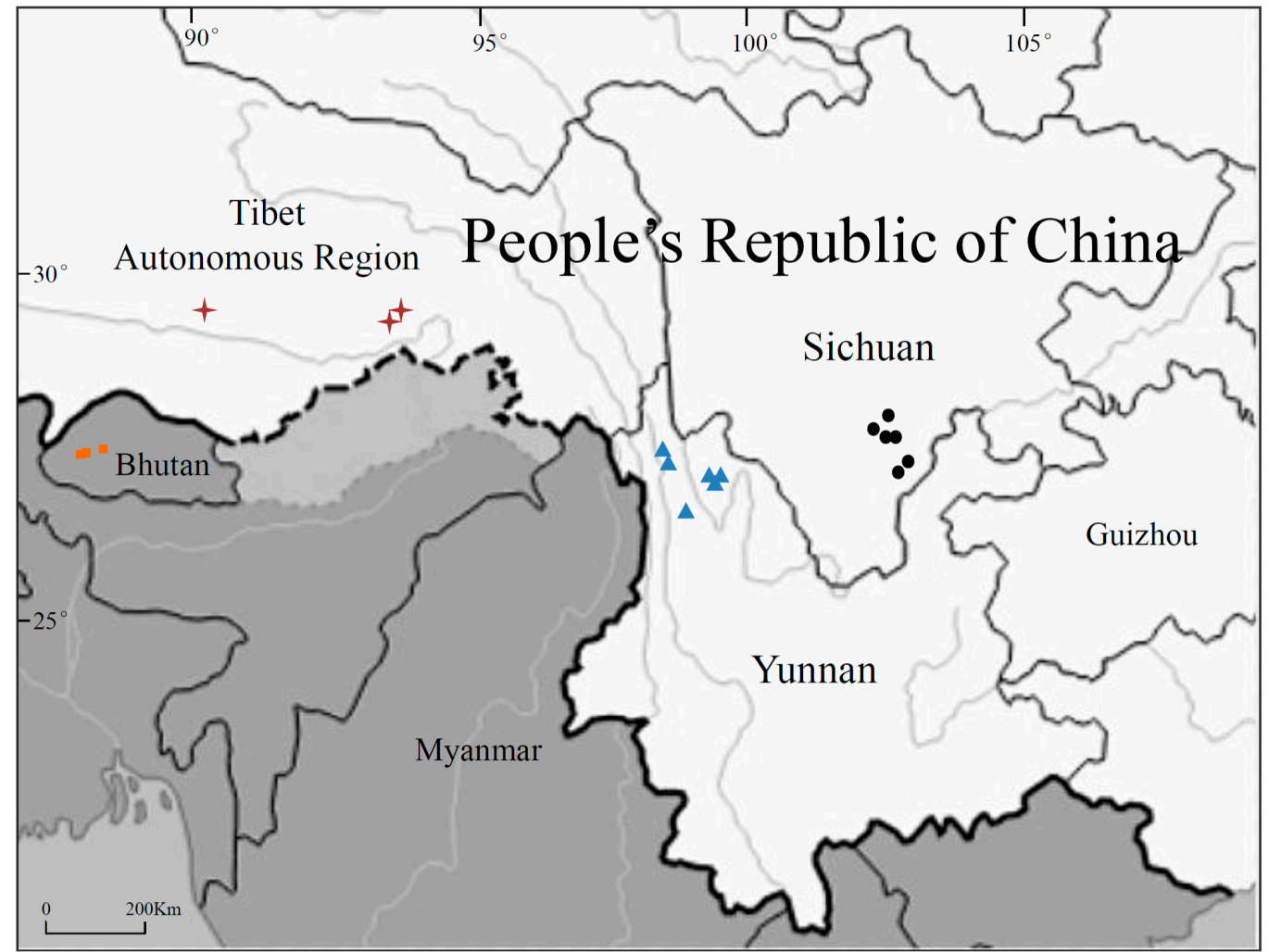

Figure 1. Study sites. Fieldwork was carried out in 18 smallholder farming communities in three regions within China (Sichuan, Yunnan \& Tibet) and two regions in Bhutan (Thimphu \& Paro). Colored symbols in the map represent specific study sites in each of the three regions of China and in Bhutan. Specifically, black circles are Yi study sites in Sichuan Province, blue triangles are Tibetan study sites in Yunnan Province, red crosses are Tibetan study sites in Tibet Autonomous Region, and orange squares are Bhutanese communities in Bhutan.

The geographic location of sampling sites ranged from $27^{\circ} 10^{\prime} \mathrm{N}$ to $29^{\circ} 38^{\prime} \mathrm{N}$ and from $89^{\circ} 24^{\prime} \mathrm{E}$ to $102^{\circ} 50^{\prime} \mathrm{E}$ (Table 1). The average altitude of sites is $2620 \mathrm{~m}$ in Sichuan, $3490 \mathrm{~m}$ in Yunnan, $3200 \mathrm{~m}$ in Tibet and $2340 \mathrm{~m}$ in Bhutan. Sichuan has a subtropical monsoon climate, Yunnan has a cold temperate climate, Tibet a temperate climate, and Bhutan wet monsoonal. The topography of Sichuan is mountain plateau while Yunnan is defined by mountain ravines, Tibet by plateaus, and Bhutan as a river valley. Tibet and Yunnan have a more complex topography compared to Sichuan and Bhutan. Yi people are the main sociolinguistic group managing buckwheat in Sichuan, Tibetans the primary group cultivating buckwheat in Yunnan and Tibet, while Bhutanese practicing Tibetan Buddhism primarily manage buckwheat in Bhutan.

\subsection{Ethnobotanical Surveys}

A total of 160 informants from 102 households were interviewed including 56 informants in Sichuan, 48 informants in Yunnan, 32 informants in Tibet, and 24 informants in Bhutan. The ethnobotanical survey tool included a series of semistructured questions [35] to procure information about number and name of buckwheat landraces managed, diet habits including dietary diversity as well as other cultural factors (Tables 1 and S1). 
Table 1. Buckwheat (Fagopyrum tataricum) sampling information based on location and associated socioecological factors.

\begin{tabular}{|c|c|c|c|c|c|c|c|c|c|c|c|}
\hline Location & Study Site & $\begin{array}{l}\text { Population } \\
\text { Code }\end{array}$ & $\begin{array}{l}\text { Number of } \\
\text { Plants }\end{array}$ & $\begin{array}{l}\text { Geographic } \\
\text { Coordinates }\end{array}$ & $\begin{array}{l}\text { Altitude } \\
(\mathrm{m})\end{array}$ & Climate & Topography & $\begin{array}{c}\text { Main } \\
\text { Sociolinguistic } \\
\text { Group }\end{array}$ & $\begin{array}{l}\text { Major Staple } \\
\text { Food }\end{array}$ & $\begin{array}{l}\text { Cultural } \\
\text { Lifestyle }\end{array}$ & Religion \\
\hline \multirow{6}{*}{ Sichuan } & Zhaojue & 1 & 6 & $\begin{array}{l}28^{\circ} 00^{\prime} 51.18^{\prime \prime} \mathrm{N} \\
102^{\circ} 50^{\prime} 38.11^{\prime \prime} \mathrm{E}\end{array}$ & 3010 & subtropical monsoon & mountain plateau & $\mathrm{Yi}$ & $\begin{array}{c}\text { tartary } \\
\text { buckwheat }\end{array}$ & farming & Bimoism \\
\hline & Zhaojue & 2 & 6 & $\begin{array}{l}28^{\circ} 03^{\prime} 18.17^{\prime \prime} \mathrm{N} \\
102^{\circ} 49^{\prime} 54.83^{\prime \prime} \mathrm{E}\end{array}$ & 2570 & subtropical monsoon & mountain plateau & Yi & $\begin{array}{c}\text { tartary } \\
\text { buckwheat }\end{array}$ & farming & Bimoism \\
\hline & Zhaojue & 3 & 6 & $\begin{array}{l}27^{\circ} 50^{\prime} 26.11^{\prime \prime} \mathrm{N} \\
102^{\circ} 47^{\prime} 08.91^{\prime \prime} \mathrm{E}\end{array}$ & 2260 & subtropical monsoon & mountain plateau & Yi & $\begin{array}{c}\text { tartary } \\
\text { buckwheat }\end{array}$ & farming & Bimoism \\
\hline & Zhaojue & 4 & 6 & $\begin{array}{l}27^{\circ} 54^{\prime} 03.10^{\prime \prime} \mathrm{N} \\
102^{\circ} 50^{\prime} 18.16^{\prime \prime} \mathrm{E}\end{array}$ & 2980 & subtropical monsoon & mountain plateau & Yi & $\begin{array}{c}\text { tartary } \\
\text { buckwheat }\end{array}$ & farming & Bimoism \\
\hline & Butuo & 5 & 5 & $\begin{array}{l}27^{\circ} 42^{\prime} 41.91^{\prime \prime} \mathrm{N} \\
102^{\circ} 49^{\prime} 06.09^{\prime \prime} \mathrm{E}\end{array}$ & 2450 & subtropical monsoon & mountain plateau & Yi & $\begin{array}{c}\text { tartary } \\
\text { buckwheat }\end{array}$ & farming & Bimoism \\
\hline & Butuo & 6 & 5 & $\begin{array}{l}27^{\circ} 44^{\prime} 26.78^{\prime \prime} \mathrm{N} \\
102^{\circ} 47^{\prime} 01.00^{\prime \prime} \mathrm{E}\end{array}$ & 2460 & subtropical monsoon & mountain plateau & Yi & $\begin{array}{c}\text { tartary } \\
\text { buckwheat }\end{array}$ & farming & Bimoism \\
\hline \multirow{6}{*}{ Yunnan } & Weixi & 7 & 5 & $\begin{array}{c}27^{\circ} 10^{\prime} 39.00^{\prime \prime} \mathrm{N} \\
99^{\circ} 17^{\prime} 57.75^{\prime \prime} \mathrm{E}\end{array}$ & 2590 & cold temperate & mountain ravines & Tibetan & hulless barley & nomadic & Buddhism \\
\hline & Deqin & 8 & 5 & $\begin{array}{c}28^{\circ} 29^{\prime} 02.26^{\prime \prime} \mathrm{N} \\
98^{\circ} 56^{\prime} 32.30^{\prime \prime} \mathrm{E}\end{array}$ & 4360 & cold temperate & mountain ravines & Tibetan & hulless barley & nomadic & Buddhism \\
\hline & Deqin & 9 & 5 & $\begin{array}{c}28^{\circ} 27^{\prime} 06.58^{\prime \prime} \mathrm{N} \\
98^{\circ} 54^{\prime} 23.39^{\prime \prime} \mathrm{E}\end{array}$ & 3280 & cold temperate & mountain ravines & Tibetan & hulless barley & nomadic & Buddhism \\
\hline & Shangri-La & 10 & 6 & $\begin{array}{c}27^{\circ} 49^{\prime} 37.07^{\prime \prime} \mathrm{N} \\
99^{\circ} 42^{\prime} 25.15^{\prime \prime} \mathrm{E}\end{array}$ & 3280 & cold temperate & mountain ravines & Tibetan & hulless barley & nomadic & Buddhism \\
\hline & Shangri-La & 11 & 6 & $\begin{array}{c}27^{\circ} 43^{\prime} 19.63^{\prime \prime} \mathrm{N} \\
99^{\circ} 46^{\prime} 06.74^{\prime \prime} \mathrm{E}\end{array}$ & 3920 & cold temperate & mountain ravines & Tibetan & hulless barley & nomadic & Buddhism \\
\hline & Shangri-La & 12 & 6 & $\begin{array}{l}27^{\circ} 28^{\prime} 51.87^{\prime \prime} \mathrm{N} \\
99^{\circ} 52^{\prime} 52.37^{\prime \prime} \mathrm{E}\end{array}$ & 3500 & cold temperate & mountain ravines & Tibetan & hulless barley & nomadic & Buddhism \\
\hline \multirow{3}{*}{ Tibet } & Lhasa & 13 & 5 & $\begin{array}{c}29^{\circ} 38^{\prime} 46.80^{\prime \prime} \mathrm{N} \\
91^{\circ} 08^{\prime} 25.02^{\prime \prime} \mathrm{E}\end{array}$ & 3650 & plateau temperate & Tibetan plateau & Tibetan & hulless barley & nomadic & Buddhism \\
\hline & Linzhi & 14 & 5 & $\begin{array}{c}29^{\circ} 38^{\prime} 57.02^{\prime \prime} \mathrm{N} \\
94^{\circ} 21^{\prime} 41.70^{\prime \prime} \mathrm{E}\end{array}$ & 3000 & plateau temperate & Tibetan plateau & Tibetan & hulless barley & nomadic & Buddhism \\
\hline & Milin & 15 & 5 & $\begin{array}{c}29^{\circ} 12^{\prime} 57.47^{\prime \prime} \mathrm{N} \\
94^{\circ} 12^{\prime} 49.08^{\prime \prime} \mathrm{E}\end{array}$ & 2940 & plateau temperate & Tibetan plateau & Tibetan & hulless barley & nomadic & Buddhism \\
\hline \multirow{3}{*}{ Bhutan } & Thimphu & 16 & 10 & $\begin{array}{c}27^{\circ} 28^{\prime} 21.79^{\prime \prime} \mathrm{N} \\
89^{\circ} 38^{\prime} 20.70^{\prime \prime} \mathrm{E}\end{array}$ & 2340 & wet monsoonal & mountain valley & Bhutanese & wheat & farming & Buddhism \\
\hline & Paro & 17 & 10 & $\begin{array}{l}27^{\circ} 25^{\prime} 45.30 \mathrm{~N} \\
89^{\circ} 24^{\prime} 59.72^{\prime \prime} \mathrm{E}\end{array}$ & 2270 & wet monsoonal & mountain valley & Bhutanese & wheat & farming & Buddhism \\
\hline & Paro & 18 & 10 & $\begin{array}{l}27^{\circ} 27^{\prime} 08.94 \mathrm{~N} \\
89^{\circ} 26^{\prime} 01.41^{\prime \prime} \mathrm{E}\end{array}$ & 2410 & wet monsoonal & mountain valley & Bhutanese & wheat & farming & Buddhism \\
\hline
\end{tabular}




\subsection{Sample Collections}

A total of 114 buckwheat (Fagopyrum tataricum) individuals were randomly sampled from 18 study populations (Table 1). Coordinates of each population were recorded. Morphological characteristics including plant height $(\mathrm{cm})$, number of branches, grain weight per plant $(\mathrm{g})$, and TGW (thousand grain weight, in g) of each sample was documented (Supplementary Table S1). Leaves from each sample were collected, silica-dried, and stored at $-20^{\circ} \mathrm{C}$ for laboratory analysis.

\subsection{DNA Isolation, PCR Amplification and Sequencing}

Three candidate loci $(r n \mathrm{H}-p s b \mathrm{~A}, r b c \mathrm{~L}-\mathrm{a}$ and $t r n \mathrm{~L}-\mathrm{F})$ from the chloroplast were used as DNA barcodes to assess sequence variation and construct phylogenetic trees among buckwheat samples. We amplified the $r b c \mathrm{~L}$ and $t r n \mathrm{~F}-\mathrm{L}$ regions using standard plastid barcoding methods, and the $t r n \mathrm{H}-p s b \mathrm{~A}$ region was amplified using primers $t r n \mathrm{H} / p s b \mathrm{~A}[3]$.

DNA was isolated from leaf samples using CTAB (cetyltrimethylammonium bromide) method [36]. The relative purity and concentration of extracted DNA was estimated by ethidium bromide staining on agarose gels compared with known DNA concentration markers. PCR amplification was performed in a $25 \mu \mathrm{L}$ reaction mixture containing $2.5 \mu \mathrm{L}$ of $10 \times$ PCR (Polymerase Chain Reaction) buffer, $2.0 \mu \mathrm{L}$ of $25 \mathrm{mmol} / \mathrm{L} \mathrm{MgCl} 2,2.5 \mu \mathrm{L}$ of $2.5 \mathrm{mmol} / \mathrm{L}$ dNTPs, $0.5 \mu \mathrm{L}$ of each primer $(10 \mu \mathrm{mol} / \mathrm{L}), 0.5$ unit of Taq DNA polymerase (Invitrogen, Carlsbad, CA, USA), $1 \mu \mathrm{L}$ of genomic DNA $(\sim 30 \mathrm{ng})$ and $\mathrm{dd}_{2} \mathrm{O}$. The reaction was carried out in an Eppendorf thermal cycler (Eppendorf, Germany). The PCR product was separated in $1 \%$ agarose gel, and the bands were visualized in a gel documentation imaging system (Bio-Rad, Hercules, CA, USA). DNA sequencing was completed by Biosune Co., Ltd. (Beijing, China). DNA sequences were deposited in Genbank (Table 2).

\subsection{Genetic Analysis}

Sequences were assembled and aligned by Clustal X software [37] and adjusted manually in CodonCode Aligner [38]. PCR results and properties of the three DNA barcoding regions of tartary buckwheat samples were analyzed by MEGA6 [39]. Genetic distance was computed by Kimura two-parameter (K2P) model with MEGA6. A Neighbor-Joining tree and a Maximum Parsimony tree based on single locus or combined loci were constructed by MEGA6 with bootstrap testing of 1000 replicates. Outgroup comparisons were made using Fagopyrum esculentum samples from Inner Mongolia as well as F. dibotrys and F. tibeticum sequence data from Genbank.

Sequence data of $\mathrm{F}$. tataricum samples were analyzed using a series of genetic diversity indexes including gene polymorphisms, nucleotide diversity, and haplotype diversity by MEGA6 and DnaSP5 software [40]. MEGA6 was used for the alignment of multiple sequences and to remove clutter sequences. DnaSP5 was applied to the analysis of nucleotide polymorphisms from aligned DNA sequence data among populations. In order to compare the sequenced locus, a series of genetic diversity indexes including the number of polymorphic sites, nucleotide diversity, average number of nucleotide differences, number of haplotypes, and haplotype (gene) diversity were calculated with MEGA6 and DnaSP 5. Haplotype analyses with and without gaps and indels were performed using DnaSP program. Phylogenetic trees were constructed on the basis of DNA polymorphisms by MEGA6 to distinguish samples from different groups, including the neighbor-joining tree based on single locus $\operatorname{trn} H-\mathrm{psb} A$ gene as well as the maximum parsimony tree by combining the three study loci for double check. Compared to the other two loci, the $\operatorname{trn} H$-psb $A$ gene provides the highest intraspecies variation and discriminating ability in the chloroplast that has the potential to determine genetic polymorphism. 


\subsection{Statistical Analysis}

Data from ethnobotanical surveys regarding number of buckwheat landraces managed and identified by farmers, level of dietary dependence on buckwheat, and geographic area were integrated with morphological and genetic data in order to examine the relationship of cultural factors and morphological variables with DNA polymorphisms and genetic divergence of buckwheat samples (Supplementary Table S2). A one-way analysis of variance (ANOVA) based on the Mann-Whitney test, Kruska-Wallis test, and Kolmogorov-Smirnov test were applied to examine statistical relationships.

\section{Results}

\subsection{Ethnobotanical Survey}

Most households interviewed in Yunnan, Tibet, and Bhutan follow a nomadic lifestyle of herding, whereas the Yi households interviewed in Sichuan depend on farming for their livelihood, with a focus on buckwheat cultivation.

Informants manage and name buckwheat landraces on the basis of multiple phenotype characteristics including seed color (including grey, black, and brown), seed shape, seed size, plant height, and flower color (Supplementary Table S1). A total of 12 farmer-named landraces were managed and identified during surveys in China. Tibetan informants in Yunnan manage and identify the greatest number of buckwheat landraces including the following seven: Bian Zi Qiao, Hong Xiao Ku Qiao, Yuan Zi Qiao, Hei Zi Qiao, Da Ku Qiao, Ku Qiao, and Hui Ku Qiao. Ku Qiao, a landrace with a brown colored seed, was the most frequently documented buckwheat in Yunnan. A total of three buckwheat landraces were identified in Sichuan by Yi with E Luo Wu Ci being the most frequently mentioned landrace (by $50 \%$ of the households) followed by E Luo Wu Qie (mentioned by $33 \%$ of the households). Both the frequently mentioned landraces by Yi smallholders are recently introduced 'improved' varieties that have a relatively large plant biomass. Informants in Tibet named three buckwheat landraces while one buckwheat landrace was named by informants in Bhutan.

Dietary dependence on buckwheat as a staple food varies geographically and by sociolinguistic group (Table 2). The Yi have the greatest dietary dependent on buckwheat as a staple grain while hull-less barley is the staple dietary crop of Tibetans. The Bhutanese rely on a series of crops including buckwheat, wheat, barley, and corn. Yi smallholders were the only informants that reported that buckwheat is mentioned in their cultural stories and is part of their rituals including sacrificial practices, hosting guests, and celebrating weddings. Tibetan households mentioned barley to be the dietary grain that plays a central role in their rituals, while Bhutanese smallholders mentioned a series of crops.

\subsection{Genetic Analysis}

A total of 90 sequences were successfully obtained from the 114 samples of buckwheat that were amplified by the three loci $r b c \mathrm{~L}-\mathrm{a}, \operatorname{trn} \mathrm{H}-p s b \mathrm{~A}$, and $\operatorname{trn} \mathrm{L}-\mathrm{F}$ and 24 sequences were unsuccessfully sequenced (Table 2). The three loci had different performance for the amplification of different buckwheat varieties. The $r b c \mathrm{~L}$-a sequence had a $90 \%$ success rate of amplification with the greatest performance for buckwheat samples from Sichuan, Yunnan, and Bhutan. trnL-F had the lowest performance rate with less than $50 \%$ rate of amplification while the $t r n \mathrm{H}-p s b \mathrm{~A}$ locus performed well about $75 \%$ for samples from Sichuan and Yunnan.

DNA sequence variation of buckwheat samples was notably lower in populations from Sichuan managed by Yi compared to those from the other study sites (Table 2). The haplotype (gene) diversity based on the $r b c$ L-a sequence for Sichuan was 0.362 while Yunnan, Tibet, and Bhutan had higher haplotype with indices of 0.712, 0.900, and 0.668, respectively. Both phylogenetic trees (Figures 2 and 3) indicate that buckwheat samples from Sichuan had fewer clades and lower genetic diversity compared with samples from the other sites. 
Table 2. Comparative analysis of genetic diversity indexes based on genetic loci and location.

\begin{tabular}{|c|c|c|c|c|c|c|c|c|}
\hline $\begin{array}{c}\text { *Loci (Avg. } \\
\text { Sequence Length) }\end{array}$ & ${ }^{* *}$ Groups & $\begin{array}{l}\text { Number of } \\
\text { Amplified } \\
\text { Sequences }\end{array}$ & $\begin{array}{l}\text { Number of } \\
\text { Polymorphic } \\
\text { Sites }\end{array}$ & $\begin{array}{c}\text { Nucleotide } \\
\text { Diversity (Pi) }\end{array}$ & $\begin{array}{c}\text { Avg. Number } \\
\text { of Nucleotide } \\
\text { Differences (K) }\end{array}$ & $\begin{array}{c}\text { Number of } \\
\text { Haplotypes } \\
\text { (NHap) }\end{array}$ & $\begin{array}{c}\text { Haplotype (Gene) } \\
\text { Diversity (Hd) }\end{array}$ & Genbank No. \\
\hline \multirow[t]{4}{*}{$r b c \mathrm{~L}-\mathrm{a}(633 \mathrm{bp})$} & SC & 29 & 4 & 0.00138 & 0.857 & 4 & 0.362 & $\begin{array}{l}\text { Serial No.: KP966643, } \\
\text { KP966644, KP966645, } \\
\text { KP966646 . . KP966728 }\end{array}$ \\
\hline & YN & 28 & 8 & 0.00295 & 1.968 & 6 & 0.712 & \\
\hline & $X Z$ & 5 & 3 & 0.00206 & 1.400 & 4 & 0.900 & \\
\hline & $\mathrm{BT}$ & 26 & 5 & 0.00199 & 1.262 & 4 & 0.668 & \\
\hline \multirow[t]{4}{*}{ 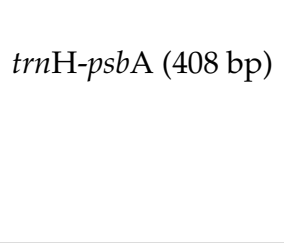 } & SC & 27 & 3 & 0.00080 & 0.291 & 4 & 0.214 & $\begin{array}{c}\text { Serial No.: KP966756, } \\
\text { KP966757, KP966758, } \\
\text { KP966759 . . KP966820 }\end{array}$ \\
\hline & YN & 23 & 5 & 0.00251 & 0.901 & 5 & 0.561 & \\
\hline & $X Z$ & 7 & 2 & 0.00180 & 0.762 & 3 & 0.524 & \\
\hline & $\mathrm{BT}$ & 8 & 2 & 0.00249 & 0.964 & 3 & 0.607 & \\
\hline \multirow[t]{4}{*}{$\operatorname{trnL}-\mathrm{F}$ (849 bp) } & SC & 5 & 1 & 0.00047 & 0.400 & 2 & 0.400 & $\begin{array}{l}\text { Serial No.: KP966729, } \\
\text { KP966730, KP966731, } \\
\text { KP966732 . . . KP966755 }\end{array}$ \\
\hline & YN & 6 & 3 & 0.00186 & 1.533 & 3 & 0.733 & \\
\hline & $X Z$ & 3 & 2 & 0.00152 & 1.333 & 2 & 0.667 & \\
\hline & $\mathrm{BT}$ & 13 & 2 & 0.00116 & 1.026 & 2 & 0.513 & \\
\hline
\end{tabular}

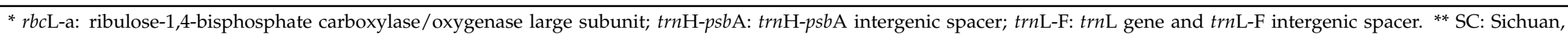
YN: Yunnan, XZ: Tibet, BT: Bhutan. 


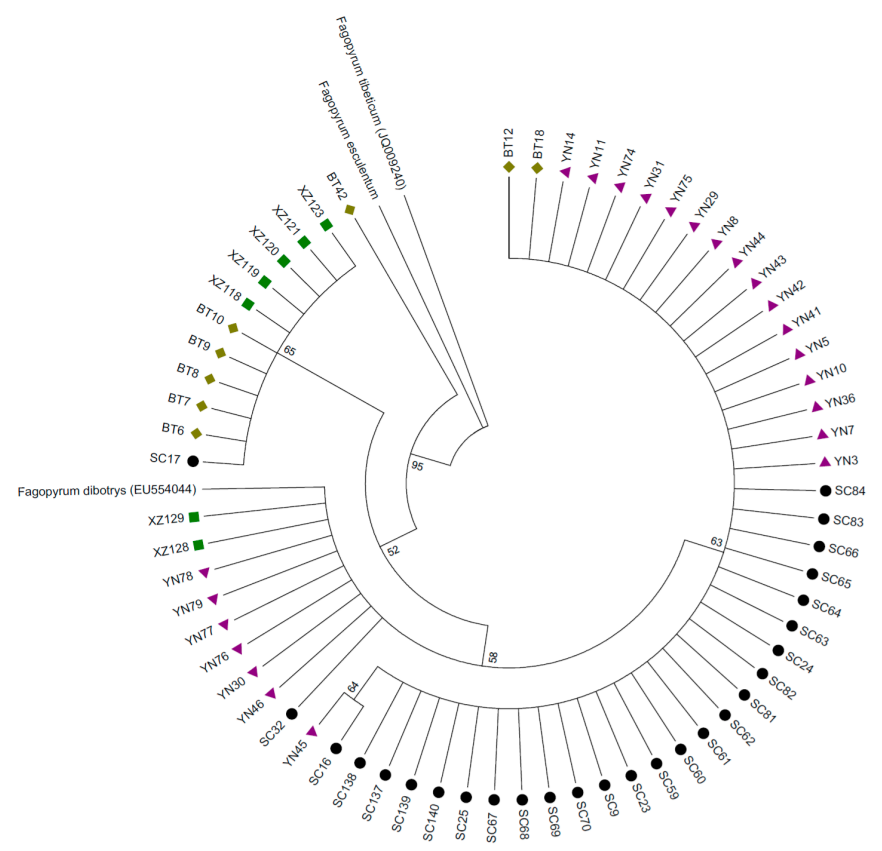

Figure 2. Phylogentic tree of $t r n \mathrm{H}-p s b \mathrm{~A}$ gene (408 bp) using the neighbor-joining method with 1000 bootstrap replications based on location. Buckwheat samples were grouped in a phylogenetic tree based on the trnH-psbA gene based on location. The following symbols $\boldsymbol{\bullet}, \boldsymbol{\Delta}, \mathbf{\square}$ and $\boldsymbol{r}$ represent samples from Sichuan, Yunnan, Tibet and Bhutan respectively. A sample of Fagopyrum esculentum collected from Inner Mongolia as well as F. dibotrys and F. tibeticum downloaded from Genbank served as outgroups). This phylogenetic tree based on the $t r n \mathrm{H}-p s b \mathrm{~A}$ gene indicates that buckwheat samples from Sichuan had fewer clades and lower genetic diversity compared with samples from the other sites.

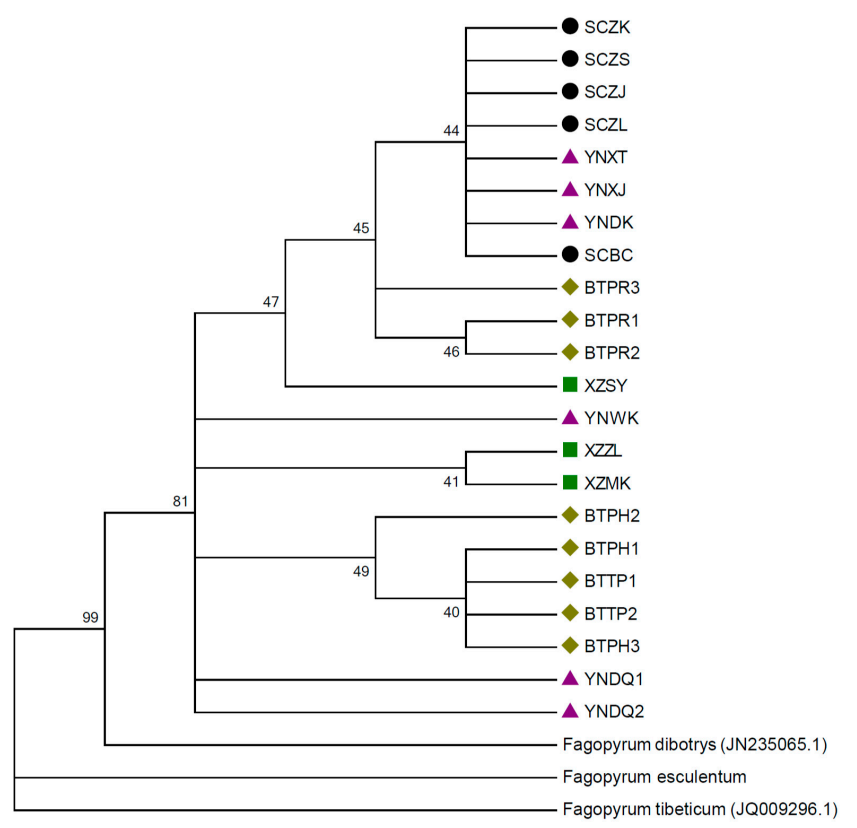

Figure 3. Phylogentic tree combining $t r n \mathrm{H}-p s b \mathrm{~A}, r b c \mathrm{~L}-\mathrm{a}$ and $t r n \mathrm{~L}-\mathrm{F}$ genes (1811 bp in total) using the maximum parsimony method with 1000 bootstrap replications based on location. The following symbols $\boldsymbol{\bullet}, \boldsymbol{\Delta}, \mathbf{\square}$ and $\boldsymbol{r}$ represent samples from Sichuan, Yunnan, Tibet and Bhutan respectively. A sample of Fagopyrum esculentum collected from Inner Mongolia as well as Fagopyrum dibotrys and Fagopyrum tibeticum downloaded from Genbank served as outgroups). This phylogenetic tree based on combining $t r n \mathrm{H}-p s b \mathrm{~A}, r b c \mathrm{~L}-\mathrm{a}$ and $t r n \mathrm{~L}-\mathrm{F}$ genes indicates that buckwheat samples from Sichuan had fewer clades and lower genetic diversity compared with samples from the other sites. 


\subsection{Correlation Analysis of Cultural, Geographic, and Morphological Factors with Genetic Differentiation}

Several cultural and geographical characters were found to be highly correlated to buckwheat genetic diversity (Figure 4 and Table S2). Specifically, greater number of buckwheat landraces managed and identified by smallholder farmers was associated with high buckwheat genetic diversity based on the three chloroplast makers. Additionally, relatively low dietary dependence of buckwheat as a staple crop was associated with higher buckwheat genetic diversity. Both these cultural factors associated with higher buckwheat genetic diversity characterize field sites in Yunnan and Tibet managed by Tibetan farmers that rely on hull-less barley as a dietary staple. Conversely, low buckwheat genetic diversity was associated with high dietary dependence of buckwheat as a staple crop in field sites in Sichuan managed by Yi. Significant relationships were found between morphological characters and genetic relatedness of individuals for plant height, number of branches, grain weight per plant, and total grain weight (Table S3).
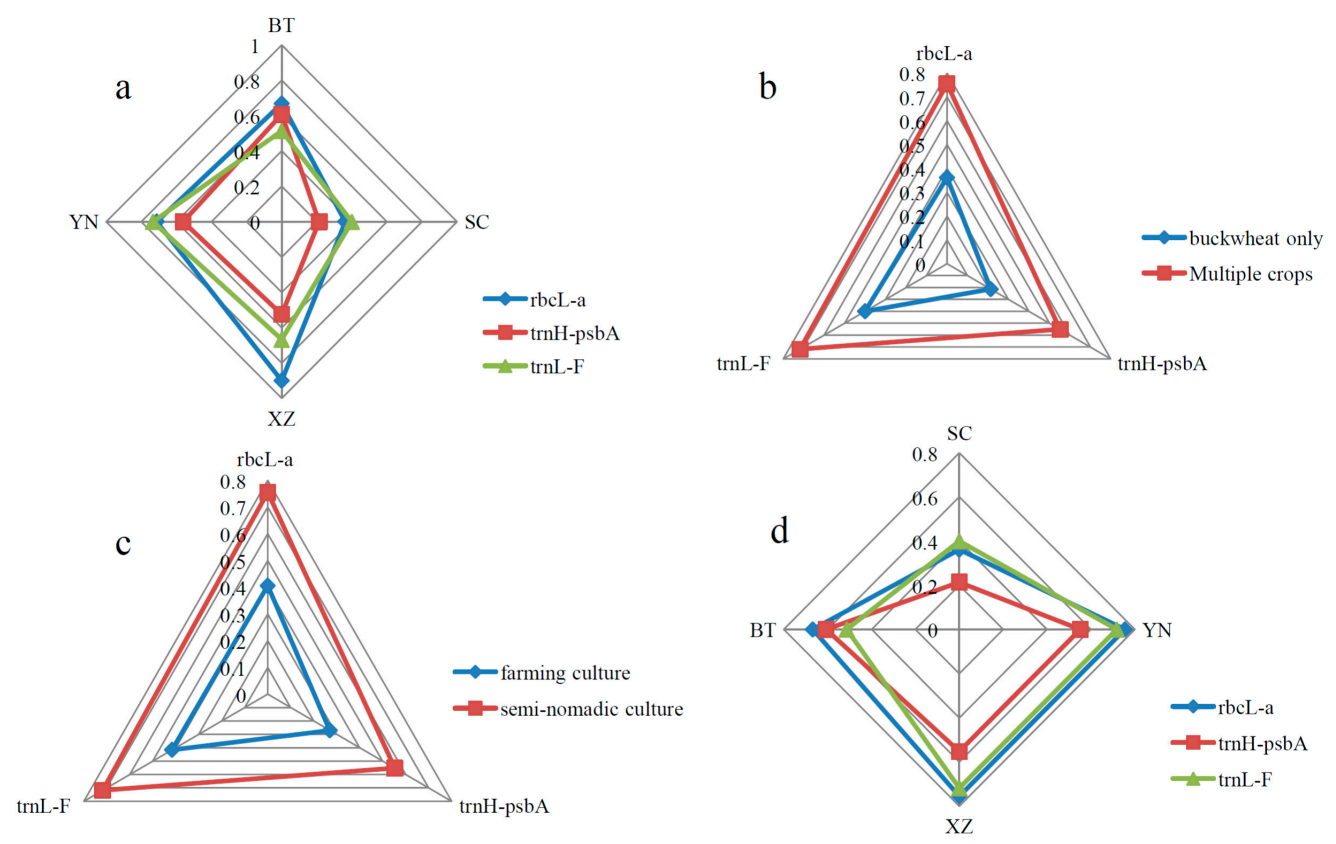

Figure 4. Correlation analysis of cultural, geographic, and morphological factors associated with genetic differentiation of buckwheat. Several cultural, geographic, and morphological factors were found to be highly correlated to buckwheat genetic diversity including greater number of buckwheat landraces managed and identified by smallholder farmers and relatively low dietary dependence of buckwheat as a staple crop. (a) Represents the geographic location factor (Sichuan, Tibet, Yunnan, and Bhutan); (b) represents the factor of dietary dependence on tartary buckwheat; (c) represents the factor of lifestyle (farming culture and seminomadic culture); (d) represents the factor of level of landraces maintained in different areas. Values from 0-0.9 represent the genetic diversity of each gene. The following letter abbreviations represent the following study site locations: SC: Sichuan, YN: Yunnan, XZ: Tibet, BT: Bhutan.

\section{Discussion}

Despite the importance of crop genetic diversity for ecological processes and food security, few cross-cultural studies have examined the relationship between cultural factors and crop genetic diversity $[6,42,43]$. This study integrates ethnobotanical surveys and DNA barcoding to examine the relationship between cultural, geographical, and morphological factors with buckwheat genetic diversity. Results support our hypothesis that smallholder communities that manage and identify a greater number of buckwheat landraces also maintain greater genetic diversity of this resource. Findings further support our hypothesis that geographic factors are associated with genetic 
differentiation of buckwheat. Surprisingly, the results were inverse of our hypothesis-that smallholder farming communities that have greater dietary dependence on buckwheat also manage greater genetic diversity of this resource in their agricultural systems. Buckwheat samples from agricultural systems managed by the Yi showed relatively low genetic polymorphisms compared to those managed by Tibetan and Bhutanese smallholder farmers.

The relatively low genetic diversity of buckwheat managed by the Yi of Sichuan is likely due to both environmental and cultural factors, including having a relatively flat terrain that is suitable for large-scale cultivation, high dietary dependence on buckwheat as a staple crop, and limited access to diverse seed sources because of policy and a lack of exchange through social networks [44]. The study sites in Sichuan have a low latitude that is relatively flat with less complex topography compared to the other sites. This flat terrain allows for large-scale and intensive production of buckwheat. Conversely, the relatively varied, montane, and harsh environmental conditions of Tibet and Yunnan are not conducive for the cultivation of buckwheat on a large scale and contribute to geographical isolation, a factor that has been extensively documented to be associated with high crop diversity and overall biodiversity [45]. Likewise, the study sites in Bhutan are mountainous with a varied landscape that is recognized to foster crop biodiversity [46]. The study sites in both Bhutan and Sichuan were characterized by a farming lifestyle where agriculture is the main source of livelihood.

Yi communities in Sichuan have high dietary dependence on buckwheat with this crop being their dietary staple, while Tibetan and Bhutanese communities have lower dietary dependence on this grain. The cultural identity of the Yi is further linked to buckwheat with its prominence in their stories and rituals. The dietary dependence of the Yi on buckwheat likely promoted its large-scale cultivation with selection of a few 'pure' landraces that were favored for specific desired characteristics such as high-yield, drought resistance, and flavor. Similar results were reported by Idrissi et al. [47] for lentil landraces from Morocco, where environmental stress, drought and heat, was a limiting factor to landrace suitability providing farmers few adapted landrace options. This explained the lower diversity find among Moroccan landraces compared to those from northern Mediterranean countries. The Yi's transition from a closed, subsistence farming system to a market-oriented system further facilitates large-scale cultivation of buckwheat using a few selected landraces with desired and reliable characteristics. This pattern of reduced diversity with increased dietary dependence on a limited number of crop species and varieties, and increased commercialization is evidenced throughout our entire modern food system, and calls for greater dietary diversification and consumption of under-utilized crops [48]. Sources of diverse buckwheat seed may also no longer be available. Tibetan smallholders who were found to maintain the greatest number of buckwheat landraces as well as the greatest genetic diversity may engage in greater experimentation of crop landraces in their agricultural systems because of their lower dependence on this crop as a dietary staple, and thus lower risk. In addition, the diverse topographic conditions of the agroecosystems managed by Tibetans may foster the need to cultivate several landraces suitable for the multiple local microclimates and environmental conditions. As a self-fertilizing crop, buckwheat does not have the ability for introgression with other differentiated varieties from a different and relatively far away geographic area [49].

Seed exchange, or the lack there of, may serve as another driving mechanism for the patterns of genetic diversity. Previous studies have shown that farmers' seed sharing networks drive the gene flow of crops within a region $[9,17,18,50]$. Access to diverse crop germplasm requires that farmers have adequate income or connections without social or political constraints to acquire different crop varieties [51]. The Tibetans are most likely in this study to have the most complex social network because of their nomadic lifestyles that likely results in greater interactions with other groups. Alternatively, the Yi and Bhutanese smallholders that follow an agricultural lifestyle may experience relatively less interaction with other communities because of long distances between different communities. Ethnobotanical interviews verified that buckwheat landraces are hard to access for the Yi people of Sichuan from the market, partly because Chinese seed policy prohibits the 
marketing of crop varieties if they fail to pass government verification standards [52]; rather, Chinese seed policies focus on production and promotion of new seed varieties [53].

\section{Conclusions}

This study demonstrates that ecological and cultural factors influence crop genetic diversity of a globally minor crop serving as a dietary staple in the Himalayas, tartary buckwheat. Specifically, we demonstrated that high dietary dependence linked to a single crop can result in its lowered genetic diversity and simplification in agricultural systems despite rich cultural history. The pattern of reduced diversity with increased dietary dependence is evidenced throughout our entire modern food system and calls for greater diversification of agricultural systems as well as greater consumption of under-utilized crops. We refer, in particular, to empirical research supporting the following activities and priorities: (1) assessment of diversity and distribution of traditional crop resources, (2) studies and programs linking informatics, genetic analysis, and traditional knowledge, (3) increased access to diverse planting materials, (4) improving the value of crop genetic diversity through better management and crop breeding programs, and (5) ensuring market and non-market benefits reach the custodians of crop genetic diversity. These proposed research and outreach activities include enhancing the dialogue between farmers and scientists through a participatory approach aimed at improving smallholder agroecosystems, diets, livelihoods and global food security more broadly. Such scientific and conservation efforts are particularly essential in the context of global environmental change, as well as the need to sustainably feed a growing population with limited natural resources while supporting biodiversity of the planet.

Supplementary Materials: The following are available online at http:/ / www.mdpi.com/2071-1050/9/10/1806/s1, Table S1: Data and statistics of morphological features and genetic diversity of buckwheat from four study sites, Table S2: Correlation analysis of the relationship between buckwheat genetic diversity and socioecological factors, Table S3: Correlation analysis of the relationship between morphological characters and genetic relatedness of individual buckwheat samples.

Acknowledgments: We are grateful to the farmers of this study for sharing their knowledge, experience, and time regarding the management and cultural place of buckwheat as well as for contributing buckwheat samples for genetic analysis. Paolo Colangelo provided useful suggestions for the planning of this study. We thank the members of Bioversity International and the Ethnobotanical Laboratory at Minzu University of China for comments through this study and assistance for collecting samples. This work was supported financially by National Natural Science Foundation of China (31161140345 \& 31761143001), Minzu University of China (2015MDTD16C \& ydzxxk201618 \& YLDX01013), Ministry of Education of China and State Administration of Foreign Experts Affairs of China (B08044), and Japan Society for the Promotion of Science (JSPS/AP/109080).

Author Contributions: Chunlin Long and Weijuan Huang devised this study. Weijuan Huang and Selena Ahmed analyzed the data. Weijuan Huang, Devra I. Jarvis, Selena Ahmed and Chunlin Long wrote and revised the manuscript. Selena Ahmed and Chunlin Long are assigned as co-correspondence author.

Conflicts of Interest: The authors declare no conflicts of interest.

\section{References}

1. Hughes, A.R.; Inouye, B.D.; Johnson, M.T.J.; Underwood, N.; Vellend, M. Ecological consequences of genetic diversity. Ecol. Lett. 2008, 11, 609-623. [CrossRef] [PubMed]

2. Cavatassi, R.; Lipper, L.; Hopkins, J. The Role of Crop Genetic Diversity in Coping with Agricultural Production Shocks: Insights from Eastern Ethiopia; No. 06-17; Food and Agriculture Organization of the United Nations: Rome, Italy, 2006.

3. Jackson, L.; van Noordwijk, M.; Bengtsson, J.; Foster, W.; Lipper, L.; Pulleman, M.; Said, M.; Snaddon, J.; Vodouhe, R. Biodiversity and agricultural sustainability: From assessment to adaptive manage. Curr. Opin. Environ. Sustain. 2010, 2, 80-87. [CrossRef]

4. Johns, T.; Powell, B.; Maundu, P.; Eyzaguirre, P.B. Agricultural biodiversity as a link between traditional food systems and contemporary development, social integrity and ecological health. J. Sci. Food Agric. 2013, 93, 3433-3442. [CrossRef] [PubMed] 
5. Rana, R.B.; Garfield, C.; Sthapit, B.; Jarvis, D. Influence of socio-economic and cultural factors in rice varietal diversity management on-farm in Nepal. Agric. Hum. Values 2007, 24, 461-472. [CrossRef]

6. Jarvis, D.I.; Brown, A.H.; Cuong, P.H.; Collado-Panduro, L.; Latournerie-Moreno, L.; Gyawali, S.; Tanto, T.; Sawadogo, M.; Mar, I.; Sadiki, M.; et al. A global perspective of the richness and evenness of traditional crop-variety diversity maintained by farming communities. Proc. Natl. Acad. Sci. USA 2008, 105, 5326-5331. [CrossRef] [PubMed]

7. Tuxill, J.; Reyes, L.A.; Latournerie, L.; Cob, V.; Jarvis, D.I. All maize is not Equal: Maize Variety Choices and Mayan Foodways in Rural Yucatan, Mexico. In Pre-Columbian Foodways, Interdisciplinary Approaches to Food, Culture and Markets in Mesoamerica; Staller, J.E., Carrasco, M.D., Eds.; Springer: Berlin/Heidelberg, Germany, 2009; pp. 467-486.

8. Jarvis, D.I.; Hodgkin, T.; Brown, A.H.; Cuong, P.H.; Collado-Panduro, L.; Latournerie-Moreno, L.; Gyawali, S.; Tanto, T.; Sawadogo, M.; Mar, I.; et al. Crop Genetic Diversity in the Field and on the Farm: Principles and Applications in Research Practices; Yale University Press: New Haven, CT, USA, 2016.

9. Labeyrie, V.; Rono, B.; Leclerc, C. How social organization shapes crop diversity: An ecological anthropology approach among Tharaka farmers of Mount Kenya. AgriC. Hum. Values 2014, 31, 97-107. [CrossRef]

10. Ahmed, S.; Peters, C.M.; Long, C.L.; Meyer, R.; Unachukwu, U.; Litt, A.; Kennelly, E.; Stepp, J.R. Biodiversity and phytochemical quality in indigenous and state-supported tea management systems of Yunnan, China. Conserv. Lett. 2013, 6, 28-36. [CrossRef]

11. Altieri, M.A. Linking ecologists and traditional farmers in the search for sustainable agriculture. Front. Ecol. Environ. 2004, 2, 35-42. [CrossRef]

12. Bisht, I.S.; Mehta, P.S.; Bhandari, D.C. Traditional crop diversity and its conservation on-farm for sustainable agricultural production in Kumaon Himalaya of Uttaranchal state: A case study. Genet. Resour. Crop Evol. 2007, 54, 345-357. [CrossRef]

13. Jarvis, D.I.; Hodgkin, T.; Sthapit, B.R.; Fadda, C.; Lopez-Noriega, I. A heuristic framework for identifying multiple ways of supporting the conservation and use of traditional crop varieties within the agricultural production system. Crit. Rev. Plant Sci. 2011, 30, 125-176. [CrossRef]

14. Pardo-de-Santayana, M.; Macía, M.J. Biodiversity: The benefit of traditional knowledge. Nature 2015, 518, 487-488. [CrossRef] [PubMed]

15. Duc, G.; Bao, S.; Baum, M.; Redden, B.; Sadiki, M.; Suso, M.J.; Vishniakova, M.; Zong, X.X. Diversity maintenance and use of Vicia faba L. genetic resources. Field Crop Res. 2010, 115, 270-278. [CrossRef]

16. Longley, C. A Social Life of Seeds: Local Management of Crop Variability in North-Western Sierra Leone. Ph.D. Thesis, University of London, London, UK, 2000.

17. Deu, M.; Sagnard, F.; Chantereau, J.; Calatayud, C.; Hérault, D.; Mariac, C.; Pham, J.-L.; Vigouroux, Y.; Kapran, I.; Traore, P.S.; et al. Nigerwide assessment of in situ sorghum genetic diversity with microsatellite markers. Theor. Appl. Genet. 2008, 116, 903-913. [CrossRef] [PubMed]

18. Delêtrea, M.; McKey, D.B.; Hodkinson, T.R. Marriage exchanges, seed exchanges, and the dynamics of manioc diversity. Proc. Natl Acad. Sci. USA 2011, 108, 18249-18254. [CrossRef] [PubMed]

19. Leclerc, C.; d'Eeckenbrugge, G.C. Social organization of crop genetic diversity. The $\mathrm{G} \times \mathrm{E} \times \mathrm{S}$ interaction model. Diversity 2012, 4, 1-32. [CrossRef]

20. Ohnishi, O. Discovery of new Fagopyrum species and its implication for the studies of evolution of Fagopyrum and of the origin of cultivated buckwheat. In Current Advances in Buckwheat Research; Matano, T., Ujihara, A., Eds.; Shinshu University Press: Nagano, Japan, 2016; Volume I-III, pp. 175-190.

21. Jones, M.K.; Liu, X.Y. Origins of agriculture in East Asia. Science 2009, 324, 730. [CrossRef] [PubMed]

22. Tsuji, K.; Ohnishi, O. Phylogenetic relationships among wild and cultivated tartary buckwheat (Fagopyrum tataricum Gaertn.) populations revealed by AFLP analyses. Genes Genet. Syst. 2001a, 76, 47-52. [CrossRef]

23. Tsuji, K.; Ohnishi, O. Phylogenetic position of east Tibetan natural populations in tatary buckwheat (Fagopyrum tataricum Gaertn.) revealed by RAPD analyses. Genet. Resour. Crop Evol. 2001, 48, 63-67. [CrossRef]

24. Senthilkumaran, R.; Bisht, I.S.; Bhat, K.V.; Rana, J.C. Diversity in buckwheat north-western Indian Himalayas. Genet. Resour. Crop Evol. 2008, 55, 287-302. [CrossRef]

25. Zhou, X.L.; Wen, L.; Li, Z.; Zhou, Y.; Chen, Y.; Lu, Y. Advance on the benefits of bioactive peptides from buckwheat. Phytochem. Rev. 2015, 14, 381-388. [CrossRef] 
26. Wu, D. Buckwheat, globalization and the reproduction of Yi culture. China Agric. Univ. J. (Soc. Sci. Ed.) 2011, 3, 193-197. (In Chinese)

27. Jarvis, D.I. Pollen evidence of changing Holocene monsoon climate in Sichuan Province, China. Quat. Res. 1993, 39, 325-337. [CrossRef]

28. Stoeckle, M. Taxonomy, DNA and the barcode of life. BioScience 2003, 53, 2-3. [CrossRef]

29. Hajibabaei, M.; Singer, G.A.; Hebert, P.D.; Hickey, D.A. DNA barcoding: how it complements taxonomy, molecular phylogenetics and population genetics. TRENDS Genet. 2007, 23, 167-172. [CrossRef] [PubMed]

30. Hou, S.; Sun, Z.; Linghu, B.; Xu, D.; Wu, B.; Zhang, B.; Wang, X.; Han, Y.; Zhang, L.; Qiao, Z.; et al. Genetic diversity of buckwheat cultivars (Fagopyrum tartaricum Gaertn.) assessed with SSR markers developed from genome survey sequences. Plant Mol. Biol. Rep. 2016, 34, 233-241. [CrossRef]

31. Zhang, Z.; Zhao, L. Molecular characterization of genetic diversity of underutilized crops: Buckwheat as an example. Acta Hort. 2013, 979, 407-419. [CrossRef]

32. Tsuji, K.; Ohnishi, O. Origin of cultivated Tatary buckwheat (Fagopyrum tataricum Gaertn.) revealed by RAPD analyses. Genet Resour Crop Ev. 2000, 47, 431-438.

33. Li, C.H.; Kobayashi, K.; Yoshida, Y.; Ohsawa, R. Genetic analyses of agronomic traits in Tartary buckwheat (Fagopyrum tataricum (L.) Gaertn.). Breeding Sci. 2012, 62, 303-309. [CrossRef] [PubMed]

34. Neuhoff, D.; Tashi, S.; Rahmann, G.; Denich, M. Organic agriculture in Bhutan: Potential and challenges. Org. Agric. 2014, 4, 209-221.

35. Silva, H.C.; Caraciolo, R.L.F.; Marangon, L.C.; Ramos, M.A.; Santos, L.L.; Albuquerque, U.P. Evaluating different methods used in ethnobotanical and ecological studies to record plant biodiversity. J. Ethnobiol. Ethnomedi. 2014, 10, 48. [CrossRef] [PubMed]

36. Murray, M.G.; Thompson, W.F. Rapid isolation of high molecular weight plant DNA. Nucleic Acids Res. 1980, 8, 4321-4326. [CrossRef] [PubMed]

37. Larkin, M.A. Clustal W and Clustal X version 2.0. Bioinformatics 2007, 23, 2947-2948. [CrossRef] [PubMed]

38. Kischner, R. Cercosporella and Ramularia. Mycologia 2009, 101, 110. [CrossRef]

39. Tamura, K.; Stecher, G.; Peterson, D.; Filipski, A.; Kumar, S. MEGA6: Molecular evolutionary genetics analysis version 6.0. Mol. Biol. Evol. 2013, 30, 2725-2729. [CrossRef] [PubMed]

40. Librado, P.; Rozas, J. DnaSP v5: A software for comprehensive analysis of DNA polymorphism data. Bioinformatics 2009, 25, 1451-1452. [CrossRef] [PubMed]

41. Hajiahmadi, Z.; Talebi, M.; Sayed-Tabatabaei, B.E. Studying genetic variability of Pomegranate (Punica granatum L.) based on chloroplast DNA. Mol. Biotechnol. 2013, 55, 249-259. [CrossRef] [PubMed]

42. Brush, S.B. Genes in the Field: On-Farm Conservation of Crop Diversity; International Plant Genetic Resources Institute: Rome, Italy, 2000.

43. Vigouroux, Y.; Barnaud, A.; Scarcelli, N.; Thuillet, A.C. Biodiversity, evolution and adaptation in cultivated crops. C.R. Biol. 2011, 334, 450-457. [CrossRef] [PubMed]

44. Coomes, O.T.; McGuire, S.J.; Garine, E.; Caillon, S.; Mckey, D.; Demeulenaere, E.; Javis, D.; Aistara, G.; Barnaud, A.; Clouvel, P.; et al. Farmer seed networks make a limited contribution to agriculture? Four common misconceptions. Food Policy 2015, 56, 41-50. [CrossRef]

45. Pfeifer, M.; Jetschke, G. Influence of geographical isolation on genetic diversity of Himantoglossum hircinum (Orchidaceae). Folia Geobot. 2006, 41, 3-20. [CrossRef]

46. Banerjee, A.; Bandopadhyay, R. Biodiversity hotspot of Bhutan and its sustainability. Curr. Sci. 2016, 110, 521-527. [CrossRef]

47. Idrissi, A.; Ouazzani, N. Contribution of morphological descriptors to the inventory and identification of olive (Olea europaea L.) varieties. Plant Genet. Resour. Newsl. 2003, 136, 1-10.

48. IAASTD. Agriculture at a Crossroads; McIntyre, B.D., Herren, H.R., Wakhungu, J., Watson, R.T., Eds.; International Assessment of Agricultural Knowledge, Science and Technology for Development (Island Press): Quezon, Philippines, 2009; pp. 65-86.

49. Chrungoo, N.K.; Sangma, S.C.; Bhatt, V.; Raina, S.N. Wild Crop Relatives: Genomic and Breeding Resources; Kole, C., Ed.; Springer: Berlin/Heidelberg, Germany, 2011; pp. 293-307.

50. Hodgkin, T.; Rana, R.; Tuxill, J.; Balma, D.; Subedi, A.; Mar, I.; Karamura, D.; Valdivia, R.; Collado, L.; Latournerie, L.; et al. Seed Systems and Crop Genetic Diversity in Agroecosystems; Jarvis, D.I., Padoch, C., Cooper, D., Eds.; Managing Biodiversity in Agricultural Ecosystems (Columbia University Press): New York, NY, USA, 2007; pp. 77-116. 
51. Sperling, L. When Disaster Strikes: A Guide for Assessing Seed Security; CIAT: Cali, Colombia, 2008.

52. Li, Y.H.; Dong, C.Y. On amendment and improvement of the PRC seed law: From the perspective of variety certification system. Law Sci. Mag. 2014, 12, 57-64. (In Chinese)

53. Pan, Q.Y.; Huang, B.L.; Vernooy, R.; Song, Y.Q. Participatory plant breeding promotes variety improvement and biodiversity. Guizhou Agric. Sci. 2004, 32, 80-81. (In Chinese) 